\section{MRC Technology extends reach}

\section{By Tracey Baas, Senior Editor}

After six years of focusing on developing small molecule drug candidates and humanizing therapeutic mAbs, both mostly from U.K. sources,
MRC Technology, the commercialization arm of the country's Medical Research Council, is taking its search for new assets to Asia. MRC Technology has taken its first steps on that front through a deal with the Shanghai Institute of Biochemistry and Cell Biology, part of the Chinese Academy of Sciences.

The MRC is the U.K.'s largest publicly funded biomedical research organization. MRC Technology initially provided technology transfer services exclusively to MRC but now works with multiple charitable and academic organizations.

MRC Technology is a not-for-profit technology transfer company that offers IP management and commercial development of healthcare-related science to scientific organizations. The income

Table 1. MRC technology deals.

\begin{tabular}{|c|c|c|c|c|}
\hline Year & Indication & Collaborator & Deal & $\begin{array}{l}\text { Therapeutic } \\
\text { modality }\end{array}$ \\
\hline 2012 & Undisclosed & $\begin{array}{l}\text { Shanghai Institute } \\
\text { of Biochemistry and } \\
\text { Cell Biology (SIBCB), } \\
\text { part of the Chinese } \\
\text { Academy of Sciences }\end{array}$ & $\begin{array}{l}\text { SIBCB will share access to potential targets, which can be further developed at MRC } \\
\text { Technology's Centre for Therapeutic Discovery }\end{array}$ & $\begin{array}{l}\text { Small } \\
\text { molecules }\end{array}$ \\
\hline 2012 & $\begin{array}{l}\text { Infectious disease, } \\
\text { drug addiction and } \\
\text { autoimmune disease }\end{array}$ & $\begin{array}{l}\text { Mount Sinai School } \\
\text { of Medicine }\end{array}$ & $\begin{array}{l}\text { MRC Technology will humanize mouse antibodies created by Mount Sinai's Center for } \\
\text { Therapeutic Antibody Discovery to control infection and treat disease }\end{array}$ & $\mathrm{mAbs}$ \\
\hline 2012 & Undisclosed & $\begin{array}{l}\text { Academic research } \\
\text { institutes }\end{array}$ & $\begin{array}{l}\text { MRC Technology will provide academic research institutes free access to a } \\
\text { representative subset of 9,000 compounds in plate format from its library of 150,000 } \\
\text { small molecules. MRC Technology will have a right of first refusal to partner on } \\
\text { any resulting drug development programs and also will have joint ownership of any } \\
\text { generated data }\end{array}$ & $\begin{array}{l}\text { Small } \\
\text { molecules }\end{array}$ \\
\hline 2012 & Undisclosed & $\begin{array}{l}\text { William Harvey } \\
\text { Research Institute at } \\
\text { Barts and The London } \\
\text { School of Medicine } \\
\text { and Dentistry }\end{array}$ & $\begin{array}{l}\text { MRC Technology will screen and develop compounds to target G protein-coupled } \\
\text { receptors }\end{array}$ & $\begin{array}{l}\text { Small } \\
\text { molecules }\end{array}$ \\
\hline 2010 & Neurology & $\begin{array}{l}\text { Roche's Genentech } \\
\text { Inc. unit }\end{array}$ & $\begin{array}{l}\text { MRC Technology granted Genentech exclusive rights to develop and commercialize } \\
\text { a group of small molecule drug candidates for the potential treatment of neurological } \\
\text { diseases. Medical Research Council (MRC) will receive an upfront payment and is } \\
\text { eligible for milestones and royalties }\end{array}$ & $\begin{array}{l}\text { Small } \\
\text { molecules }\end{array}$ \\
\hline 2010 & $\begin{array}{l}\text { Cancer, } \\
\text { cardiovascular } \\
\text { disease, neurology } \\
\text { and infection }\end{array}$ & AstraZeneca plc & $\begin{array}{l}\text { MRC Technology will screen a compound library for five undisclosed targets from } \\
\text { AstraZeneca in the areas of cancer, cardiovascular disease, neurology and infection } \\
\text { and five additional targets from MRC for the same areas. The library includes 100,000 } \\
\text { compounds from the pharma and 50,000 compounds from MRC. The partners will } \\
\text { retain ownership of their respective compounds and plan to negotiate licenses for } \\
\text { projects chosen for further development. The licenses would trigger option fees to } \\
\text { MRC }\end{array}$ & $\begin{array}{l}\text { Small } \\
\text { molecules }\end{array}$ \\
\hline 2008 & Lymphoma & $\begin{array}{l}\text { Biolex Therapeutics } \\
\text { Inc. }\end{array}$ & $\begin{array}{l}\text { MRC Technology will humanize Biolex's BLX- } 301 \text { antibody, which is an optimized } \\
\text { glycosylated version of rituximab and is in preclinical development for non-Hodgkin's } \\
\text { lymphoma. Biolex will retain full rights to the antibody, and MRC will be eligible for } \\
\text { milestones and royalties }\end{array}$ & $\mathrm{mAbs}$ \\
\hline 2007 & $\begin{array}{l}\text { Alzheimer's disease } \\
\text { (AD) }\end{array}$ & $\begin{array}{l}\text { Intellect } \\
\text { Neurosciences Inc. }\end{array}$ & $\begin{array}{l}\text { MRC Technology has humanized two of Intellect's mAbs against } \beta \text {-amyloid (A } \beta \text { ) to } \\
\text { treat AD and age-related macular degeneration (AMD). Intellect is working with } \\
\text { Lonza Group Ltd. to manufacture humanized antibody and a humanized antibody } \\
\text { conjugate, called conjumab A, for lead testing and optimization. MRC Technology is } \\
\text { eligible for undisclosed milestones and royalties }\end{array}$ & $\mathrm{mAbs}$ \\
\hline 2007 & Cancer & Akzo Nobel N.V. & $\begin{array}{l}\text { MRC Technology will humanize an antibody from Akzo's Organon BioSciences N.V. } \\
\text { unit to treat cancer. MRC Technologies is eligible for milestones and royalties. Organon } \\
\text { has all rights to develop and commercialize the humanized antibody. Organon was } \\
\text { acquired by Schering-Plough Corp. (now part of Merck \& Co. Inc.) }\end{array}$ & $\mathrm{mAbs}$ \\
\hline
\end{tabular}


generated helps fund further research in the originating scientific organizations.

The company has an in-house screening facility, chemical libraries of about 120,000 compounds and the medicinal chemistry expertise of researchers at MRC Technology's Centre for Therapeutics Discovery. In addition, MRC Technology has access to about 100,000 proprietary compounds that are target-based and 22 shelved compounds through a deal with AstraZeneca plc.

Under MRC Technology's deal with the Shanghai Institute of Biochemistry and Cell Biology (SIBCB) to identify new targets for drug development, the institute will share access to potential new targets, which can be further developed at the Centre for Therapeutics Discovery.

"We are always looking for innovative science that might be attractive to pharmaceutical companies further down the drug discovery pipeline," said Michael Dalrymple, director of business development at MRC Technology.

According to Zi Zhang, MRC Technology's business development manager in charge of the partnership, "We chose SIBCB because of its long history and past achievements and because of it being recognized as a flagship institute by the Chinese life science community."

MRC Technology said it has not yet discussed financial terms or rights to IP with SIBCB.

"MRC Technology and SIBCB will share access to those potential targets and secondary assays. Any tool compounds found can be used to validate those targets in collaboration with the original principal investigator," noted Dalrymple. “Ultimately, MRC Technology's collaborative drug discovery engine relies on identifying top scientists and institutes so that we can plug into the cutting-edge biology and, working with the scientists, identify good targets."

He added, "At this stage we are target and indication agnostic. We're really just looking for interesting science that could provide potential targets for unmet medical needs. While we're not focused on unmet medical needs of China per se, if those targets shake out first, even better."

"We hope to show that collaborations in China can be successful by identifying innovative druggable targets with SIBCB and developing potent and selective novel therapeutics as quickly as we can-18-36 months would be ideal," said Dalrymple. "If or when we do show our Shanghai collaboration is successful, we already have a short list of other Chinese institutes we'd also like to reach out to."

\section{U.S. deal}

Earlier this year, MRC Technology announced a partnership to apply MRC Technology's antibody humanization capabilities to Mount Sinai School of Medicine's mouse antibodies against targets in infectious disease, drug addiction and autoimmune disease (see Table 1, "MRC Technology deals").

Mount Sinai will generate mAbs against targets that have successfully been through MRC Technology's antibody review process and selected for development. MRC Technology will provide humanization by altering the mouse antibody's molecular structure to make it compatible for therapeutic use in humans without affecting its binding specificity.

A number of MRC Technology's collaborations already have progressed beyond the screening phase at the Centre for Therapeutics Discovery. Ongoing programs include 10 different targets and span 7 indications (see Table 2, "Centre for Therapeutics Discovery").

Baas, T. SciBX 5(49); doi:10.1038/scibx.2012.1274

Published online Dec. 20, 2012

COMPANIES AND INSTITUTIONS MENTIONED

AstraZeneca plc (LSE:AZN; NYSE:AZN), London, U.K.

Chinese Academy of Sciences, Beijing, China

Medical Research Council, London, U.K.

Mount Sinai School of Medicine, New York, N.Y.

MRC Technology, London, U.K.

Shanghai Institute of Biochemistry and Cell Biology, Shanghai, China

Table 2. Centre for Therapeutics Discovery.

\begin{tabular}{|c|c|c|c|}
\hline Target & Project & $\begin{array}{l}\text { Stage of } \\
\text { development }\end{array}$ & Collaborator \\
\hline Undisclosed & Undisclosed & Hit to lead & Undisclosed \\
\hline Melanocortin 3 receptor (MC3R) & MC3R for inflammatory and mechanical joint disease & Hit to lead & $\begin{array}{l}\text { William Harvey Research Institute } \\
\text { at Barts and The London School of } \\
\text { Medicine and Dentistry }\end{array}$ \\
\hline $\begin{array}{l}\text { Formyl peptide receptor-like } 1 \\
\text { (FPRL1; FPR2) }\end{array}$ & FPR2 agonists for ischemia/reperfusion injury & Hit to lead & William Harvey Research Institute \\
\hline $\begin{array}{l}\text { Mycobacterium tuberculosis } \\
\text { glucanase GlgE (glgE) }\end{array}$ & Inhibitors of glgE to treat tuberculosis & Hit to lead & John Innes Centre \\
\hline Melanocortin 2 receptor (MC2R) & MC2R for Cushing's syndrome & Hit to lead & Queen Mary, University of London \\
\hline $\begin{array}{l}\text { MAP/microtubule affinity- } \\
\text { regulating kinase (MARK) }\end{array}$ & $\begin{array}{l}\text { Inhibitors of MARK microtubule-associated protein- } \tau \text { (MAPT; } \\
\text { TAU; FTDP-17) phosphorylation in Alzheimer's disease (AD) }\end{array}$ & Hit to lead & $\begin{array}{l}\text { MRC Protein Phosphorylation } \\
\text { Unit }\end{array}$ \\
\hline $\begin{array}{l}\text { Neurotrophic tyrosine kinase } \\
\text { receptor } 1 \text { (NTRK1; TrkA) }\end{array}$ & TrkA modulators for pain & Hit to lead & University of Bristol \\
\hline Galanin receptor 1 (GALR1) & $\begin{array}{l}\text { New allosteric modulators of the second galanin receptor subtype } \\
\text { (GALR2) to treat pain }\end{array}$ & Screening & University of Bristol \\
\hline Potassium channel Kir7.1 (KCNJ13) & Inwardly rectifying $\mathrm{KCNJ} 13$ to treat postpartum hemorrhage & Screening & The University of Warwick \\
\hline $\begin{array}{l}\text { Plasmodium falciparum exported } \\
\text { protein } 2 \text { (PKG 123420; EXP2) }\end{array}$ & Inhibitors of PKG to treat malaria & Hit to lead & $\begin{array}{l}\text { London School of Hygiene \& } \\
\text { Tropical Medicine }\end{array}$ \\
\hline
\end{tabular}

